\author{
MONIKA OSTAP-ChĘ́ ${ }^{1}$, KRZYSZTOF MiLER ${ }^{2}$ \\ ${ }^{1}$ Instytut Nauk o Środowisku \\ Wydziat Biologii \\ Uniwersytet Jagielloński \\ Gronostajowa 7, 30-387 Kraków \\ ${ }^{2}$ Instytut Systematyki i Ewolucji Zwierzat PAN \\ Sławkowska 17, 31-016 Kraków \\ E-mail: monika.ostap-chec@doctoral.uj.edu.pl \\ miler@isez.pan.krakow.pl
}

\title{
PSZCZOŁA MIODNA JAKO OBIECUJĄCY GATUNEK MODELOWY W BADANIACH NAD ALKOHOLIZMEM
}

\section{WSTEP}

Problemy zwiazane $z$ zaburzeniami spożycia alkoholu u ludzi sięgaja zapewne samych początków kontrolowanej fermentacji, datowanej na około 9000 lat temu (McGoVERN i współaut. 2004), a trwają po dziśs dzień. Mimo rosnacej wiedzy na temat alkoholizmu i coraz nowocześniejszych metod leczenia, stanowi on globalny problem, wpływając bezpośrednio na sferę psychiczna, fizyczna, a także społeczną osoby uzależnionej i jej środowiska. Problem alkoholizmu w dalszym ciagu wymaga badań o szerokim zakresie. Biorąc pod uwagę, że badania na ludziach rodza wiele ograniczeń metodologicznych i kontrowersji etycznych, niezbędne jest wykorzystywanie modeli zwierzęcych. Najpopularniejszymi gatunkami modelowymi w tej dziedzinie sa gryzonie, takie jak myszy i szczury (SPANAGEL 2000, GHOSH DASTIDAR i współaut. 2018), a spośród organizmów bezkręgowych - nicienie i muszki owocowe (SchOlZ i MustaRd 2011). Wspomniane grupy zwierzece sa popularne ze względu na to, że sa dobrymi modelami, to znaczy $z$ jednej strony upraszczają badania, a $z$ drugiej strony wyniki otrzymane $z$ ich udziałem dają się w dobrym stopniu odnieść do organizmu człowieka i przynajmniej niektórych sposobów jego funkcjonowania. Kolejnym gatunkiem, który zyskał popularność w badaniach skutków spożywania alkoholu jest pszczoła miodna Apis mellifera, organizm wykorzystywany w celach gospodarczych oraz jako model w szerokim zakresie badań, np. w neurobiologii. Zainteresowanie pszczołą miodna w kontekście badań nad alkoholizmem pojawiło się na przełomie tysiącleci i w ciagu ostatnich dwóch dekad wyraźnie wzrasta. Owo zainteresowanie wynika $z$ wyjatkowych cech pszczoły miodnej, takich jak złożona struktura społeczna, zaawansowana komunikacja czy olbrzymie zdolności uczenia się (WINSTON 1987, MENZEL 2012, ZAYED i RoBINSON 2012), które daja jej przewagę nad innymi gatunkami. Okazuje się, że pszczoła miodna nie tylko chętnie spożywa pokarm zawierajacy alkohol (etanol) i można u niej obserwować wiele skutków takiego spożycia, ale prawdopodobnie może się również od alkoholu uzależnić, co świadczy o wysokim potencjale tego modelu zwierzęcego w badaniach nad alkoholizmem. W kilku poniższych rozdziałach omówione zostały dotychczasowe kluczowe wyniki dotyczące pszczoły miodnej i wpływu, jaki ma na nia etanol.

\section{PREFERENCJE PSZCZÓE W KONTEKŚCIE SPOŻYWANIA POKARMÓW Z ETANOLEM}

Pierwsza seria eksperymentów, mająca odpowiedzieć na pytania koncentrujące się wokół tego, czy robotnice pszczoły miodnej spożywaja etanol, pochodzi z 2000 r. (ABRAMSON i współaut. 2000). Badacze roz-

Słowa kluczowe: alkohol, alkoholizm, Apis mellifera, pszczoła miodna, uzależnienie 
poczęli od przygotowania wodnego roztworu sacharozy ("roztwór cukru”, w tych i większości innych badań w stężeniu 20-60\%). Następnie podzielili go na części i rozpuścili w nich różne objętości czystego etanolu, otrzymujacc roztwory o stężeniach etanolu: $0 \%, 1 \%, 5 \%, 10 \%, 20 \%$ i $95 \%$. W warunkach laboratoryjnych mierzyli wypita przez robotnice objętość poszczególnych roztworów. Wyniki były zaskakujące, okazało się bowiem, że pszczoły piły podobne objętości (średnio około 14-16 $\mu \mathrm{l}$ ) każdego $z$ roztworów, $z$ wyjątkiem roztworu o stężeniu 95\%, którego nie piły w ogóle. Następnie autorzy skupili się na momencie zetknięcia robotnic z wyżej wymienionymi roztworami. Pszczoła przed wyciagniecciem języczka w celu napicia się, najpierw bada dany roztwór czułkami i decyduje, czy jest on dla niej atrakcyjny. Badacze mierzyli czas, przez jaki pszczoły miały wyciagnięty języczek po dotknięciu czułkiem roztworu każdego typu. W tym przypadku pszczoły wyciagały języczki przez taki sam czas (średnio około 70-90 s) w odpowiedzi na każdy kolejny roztwór, $z$ wyjątkiem tego o stężeniu 95\%, co potwierdziło wcześniejsze rezultaty o atrakcyjności oferowanych roztworów. Następnie, aby upewnić się, że stężenie alkoholu nie ma dla robotnic znaczenia, autorzy oferowali im roztwór cukru o różnych stężeniach etanolu: kolejno $10 \%$, 20\% i 95\% lub 20\%, 10\% i 95\% i notowali, czy i w odpowiedzi na który roztwór pszczoły wyciągają języczki. Robotnice zawsze reagowały na roztwory $10 \%$ i $20 \%$ bez względu na ich kolejność, a nigdy nie reagowały na roztwór o stężeniu 95\%. Wyniki te ostatecznie potwierdziły, że tylko wysoko stężone roztwory etanolu sa dla pszczół awersyjne, natomiast mniej stężone sa dla nich atrakcyjne na równi $z$ roztworem cukru. Zagłębiajac się w kwestię awersyjności etanolu, autorzy wykonali dodatkowy test, z użyciem etanolu o stężeniach 1\%, 5\%, 10\% i 20\%, ale tym razem rozpuszczonych w roztworze cukru albo w czystej wodzie. Następnie sprawdzali atrakcyjność tych roztworów, roztworu cukru i czystej wody, ponownie jako miary atrakcyjności używając czasu, przez który pszczoły miały wyciagnięte języczki po kontakcie $z$ badanymi roztworami. Okazało się, że pszczoły reagowały najdłużej na roztwór cukru i wszystkie stężenia etanolu rozpuszczone w roztworze cukru, krócej na roztwory etanolu w wodzie, a najkrócej na czysta wodę. Wyniki te pokazały, że cukier znaczaco zwiększa atrakcyjność etanolu, choć sam alkohol w wodzie też jest stosunkowo atrakcyjny dla pszczół. Co ciekawe, w dalszych badaniach ten sam zespół badaczy wykazał, że ową zaskakujaca atrakcyjność etanolu można u pszczół do pewnego stop- nia zmniejszyć podając im disulfiram, czyli lek stosowany w leczeniu alkoholizmu u ludzi (ABRAMSON i współaut. 2003). Warto jednak zaznaczyć, że lek ten działał tylko na niektóre robotnice.

W ostatnim czasie podjęto nowa, bardziej metodologicznie rygorystyczną próbę oceny preferencji pszczół w stosunku do pokarmu $z$ etanolem (MUSTARD i współaut. 2019). Co ważne, uwzględniono w tych badaniach również stosunkowo niskie stężenia etanolu. Badacze testowali odpowiedź pszczół na oferowana im czystą wodę, roztwór cukru oraz 0,313\%, 0,625\%, 1,25\%, 2,5\%, 5\%, 10\% bądź $25 \%$ stężenia etanolu rozpuszczone w roztworze cukru lub wodzie. Obserwowali oni behawior, notujac czy dana pszczoła wyciaga języczek w odpowiedzi na dotknięcie danym roztworem jej czułków, oraz mierzyli spożycie każdego $z$ roztworów (wyrażone jako objętość wypitego roztworu). Otrzymane wyniki były zbieżne dla obu obserwowanych miar atrakcyjności. Robotnice stosunkowo rzadko reagowały na czysta wodę i wypijały jej małe objętości. Niskie stężenia etanolu rozpuszczonego w wodzie (do $5 \%$ ) można na podstawie wyników uznać za nie awersyjne, gdyż pszczoły zachowywały się względem nich podobnie jak w odpowiedzi na czysta wodę. Natomiast wyższe stężenia etanolu rozpuszczonego w wodzie były dla pszczół awersyjne - robotnice przestały na nie reagować i nie chciały ich pić. Wyniki te sa bardziej zgodne $z$ intuicja, niż przytaczane wcześniej (ABRAMSON i współaut. 2000), choć trudno stwierdzić, dlaczego otrzymano tak odmienne rezultaty. Podobnie jednak jak ABRAMSON i wspólaut. (2000), MUSTARD i współaut. (2019) stwierdzili wysoka i podobna atrakcyjność roztworu cukru oraz wszystkich stężeń etanolu rozpuszczonego w roztworze cukru. Przeprowadzili oni również dodatkowy test, w którym zamykali pszczoły w pudełkach, w których miały dostęp do roztworu cukru i jednego $z$ roztworów o stężeniu etanolu równym 0,625\%, $1,25 \%, 2,5 \%, 5 \%$ lub $10 \%$ rozpuszczonym w roztworze cukru. Po 24 godzinach mierzyli, ile pszczoły wypiły każdego typu roztworu. Autorzy wykazali w tym eksperymencie, że mając wybór między czystym roztworem cu$\mathrm{kru}$, a takim $\mathrm{z}$ dodatkiem 1,25\% lub 2,5\% etanolu, pszczoły spożywały większe objętości roztworów $z$ etanolem. W przypadku pozostałych roztworów nie stwierdzono różnic w preferencjach. Te wyniki sugeruja, że robotnice nie tylko spożywaja niskoprocentowe roztwory etanolu (nawet, gdy moga tego uniknać), ale wręcz je preferuja.

ABRAMSON i współaut. (2000) wykonali także dwa eksperymenty w bardziej naturalnych warunkach terenowych. Ustawili 
oni przed ulami sztuczny karmnik $z$ roztworem cukru, a gdy liczebność odwiedzajacych pszczół się ustabilizowała, podmienili roztwór na taki $z$ dodatkiem $5 \%$ etanolu. W ciagu pół godziny od podmiany roztworów, liczebność pszczół odwiedzajacych karmnik wzrosła 5-krotnie, wskazujac jednoznacznie na wzrost atrakcyjności dostępnego tam pokarmu. W póżniejszych badaniach terenowych (ABRAMSON i współaut. 2004a, BozIC i współaut. 2006) nie wykazano już jednak podobnych preferencji pszczół w kierunku roztworu cukru $z$ dodatkiem $5 \%$ etanolu w porównaniu $z$ czystym roztworem cukru. Gdy zastosowano bardziej zaawansowany technologicznie karmnik, dzięki któremu możliwy był automatyczny pomiar objętości roztworu, jaka pobrała każda wizytujacca pszczoła, oraz częstotliwości wizyt tych samych pszczół w ciagu dnia odkryto, że podmiana czystego roztworu cukru na taki $z$ dodatkiem 5\% etanolu skutkowała zmniejszeniem pobieranej objętości roztworu i mniejszą częstotliwośca wizyt (SoKolowski i współaut. 2012). Dodatkowo odkryto również, że pszczoły bardzo wyraźnie unikały karmnika, w którym czysty roztwór cukru podmieniono na taki $z$ dodatkiem 10\% etanolu.

Reasumujac, przytoczone badania wskazuja, że pszczoły odbieraja etanol jako atrakcyjny, zwłaszcza gdy rozpuszczony jest w roztworze cukru. Należy jednak mieć na uwadze, że robotnice preferuja raczej stężenia etanolu nie przekraczające kilku procent, szczególnie w naturalnych warunkach terenowych. Pszczoły przetrzymywane w laboratorium i oderwane od naturalnego kontekstu, moga wykazywać zniekształcone zachowanie w porównaniu $z$ sytuacją $w$ terenie. $Z$ tego może wynikać rozbieżność wyników badań laboratoryjnych i terenowych, czyli zawyżona atrakcyjność etanolu stwierdzana w tych pierwszych.

\section{APETYT PO SPOŻYCIU ETANOLU}

MustaRD i współaut. (2008) badali, jak spożycie etanolu wpływa na późniejszą wrażliwość pszczół na stężenie roztworu cukru i ich motywację do pożywiania się. Wrażliwość na stężenie cukru jest ważna dla robotnic $z$ perspektywy ekologicznej, gdyż to na jej podstawie pszczoły moga np. decydować, który roztwór jest atrakcyjniejszy. W warunkach naturalnych odpowiada to decyzjom, na których kwiatach się pożywiać, gdy ich nektar różni się jakością. Badacze wykorzystali standardową metodologię, w której unieruchomionym pszczołom oferuje się różne roztwory przez dotknięcie czułka kropla każdego roztworu i obserwuje się, czy wyciagają języczek. Wyciąnnięcie języczka jest sy- gnałem, że pszczoła uznaje dany roztwór za atrakcyjny. Pszczoły najpierw zostały nakarmione niewielkimi objętościami roztworu cukru lub roztworu 2,5\%, 5\%, 10\% bacdź 25\% etanolu rozpuszczonego w roztworze cu$\mathrm{kru}$, po czym po 2 godzinach testowano ich wrażliwość na czysty roztwór cukru w stężeniach kolejno $0,1 \%, 0,3 \%, 1 \%, 3 \%, 10 \%$ i $30 \%$. Autorzy odkryli, że wcześniejsze spożycie etanolu w jakimkolwiek stężeniu nie wpłynęło na wrażliwość pszczół na cukier. Wszystkie robotnice reagowały na roztwór cukru począwszy od stężenia $1 \%$ lub $3 \%$ i na wyższe. Jednak ci sami badacze wykazali spadek apetytu mierzonego objętościa spożytego roztworu cukru u pszczół, które wcześniej zetknęły się $z$ etanolem. Około 3 godziny po karmieniu różnymi roztworami, robotnice nakarmione 5\% i 10\% etanolem rozpuszczonym w roztworze cukru spożywały istotnie mniej czystego roztworu cukru niż pszczoły nakarmione czystym roztworem cukru lub takim $z$ dodatkiem $2,5 \%$ etanolu. Po około 24 godzinach od karmienia spadek apetytu był dalej widoczny, ale już tylko w grupie pszczół, która wcześniej wypiła 10\% roztwór etanolu rozpuszczony w roztworze cukru. Prawdopodobnie jest to ilustracja działania etanolu jako inhibitora zachowania.

W powiazanych badaniach, VARNON i współaut. (2018) zadali pytanie o to, czy spożycie etanolu może wywoływać wyuczona awersję smakowa. Awersja względem konkretnego smaku pojawia się szybko, często oparta jest na pojedynczym powiazaniu zdarzeń, czyli smaku pożywienia i następujacych negatywnych konsekwencji zdrowotnych. Jej skutek jest taki, że awersja względem smaku powoduje brak apetytu na ów konkretny smak (GARCIA i KOELLING 1966, KLOSTERHALFEN i KLOSTERHALFEN 1985). Badacze karmili więc pszczoły czystym roztworem cukru lub takim $z$ dodatkiem 2,5\%, $5 \%, 10 \%$ lub 20\% etanolu o smaku lawendy (do każdego dodano odrobinę olejku lawendowego). Pół godziny później sprawdzali reakcje pszczół na roztwór cukru, który miał smak lawendy albo cynamonu. Mierzona reakcja było wyciaganie języczka po kontakcie $z$ roztworem testowym. Jeśli u robotnic spożywających wcześniej etanol rozwinęła się awersja względem smaku lawendy, to powinny one reagować na roztwór cukru o smaku cynamonowym, ale nie lawendowym. Dla pszczół wcześniej spożywających czysty roztwór cukru, jego smak nie powinien mieć znaczenia. Wyniki wskazały jednak, że mimo, iż pszczoły generalne sa zdolne do rozwinięcia awersji smakowej, to nie wykazuja jej w stosunku do pokarmów $z$ etanolem, nawet jeśli wcześniej spożywały roztwór 
etanolu o stężeniu 20\%. Zaobserwowano ogólny spadek apetytu w grupach pszczół, które na początku nakarmione zostały roztworami $z$ etanolem, szczególnie tymi o wyższej procentowości, jak w badaniach wspomnianych wyżej (MUSTARD i współaut. 2008). Stwierdzenie braku awersji do smaku powiazanego $z$ etanolem u pszczół stanowi jednak bardzo wartościowy wynik, omówiony jeszcze w dalszej części tekstu.

\section{PRZYWRÓCENIE RÓWNOWAGI FUNKCJONALNEJ PO SPOŻYCIU ETANOLU}

ABRAMSON i współaut. (2000) badali również, jak spożycie niewielkich objętości czystego roztworu cukru lub różnych stężeń etanolu $(1 \%, 5 \%, 10 \%$ i $20 \%)$ rozpuszczonych $\mathrm{w}$ roztworze cukru wplywa na pszczoły w zakresie dezorganizacji ich normalnego funkcjonowania. Pszczoły były karmione wyżej wymienionymi różnymi roztworami, a po 15 minutach oferowano im czysty roztwór cukru. Jeśli nie reagowały wyciagnięciem języczka, to po kolejnej minucie znów prezentowano ten sam czysty roztwór cukru, co badacze powtarzali tak długo, aż zanotowali reakcję. Czysty roztwór cukru jest wysoce atrakcyjny dla pszczół i reaguja one na niego praktycznie bezwarunkowo, co oznacza, że reakcję na niego można wykorzystać jako dobry wskaźnik normalnego funkcjonowania. Okazało się, że pszczoły, które wcześniej spożyły nieco czystego roztworu cukru reagowały szybko. Jednak reakcje pszczół były zaburzone, jeśli wcześniej spożyły roztwór cukru $z$ dodatkiem etanolu. W przypadku tych osobników, które były nakarmione $20 \%$ roztworem etanolu, powrót do normalności zajmował średnio aż około 4 godzin. Przy niższych stężeniach spożytego etanolu czas ten był odpowiednio krótszy. Później wykazano, że etanol rzeczywiście działa na pszczoły jak inhibitor zachowania, blokujac wiele jego form, przy czym siła tego wpływu zależy od dawki (ABRAMSON i współaut. 2015).

Spożycie etanolu o różnym stężeniu przekłada się na odpowiednio wysoki poziom etanolu $\mathrm{w}$ hemolimfie pszczół, a co istotne, etanol pojawia się $\mathrm{w}$ hemolimfie kilka minut po spożyciu i jego poziom rośnie do około pół godziny po spożyciu, nie zmieniajac się przez następne kilka godzin (MAZE i współaut. 2006, BOZIC i współaut. 2007). Do wniosków tych doszli badacze wykorzystując dwie różne metody pomiaru etanolu w hemolimfie robotnic: spektrofotometrię i chromatografię gazowa. Wyniki te wskazuja na ważny aspekt metodologiczny $\mathrm{w}$ badaniach wpływu spożycia, zwłasz- cza niskich stężeń etanolu na zachowanie pszczół: optymalne jest rozpoczęcie obserwacji po upływie około pół godziny po karmieniu.

AMMONS i HUNT (2008a) po raz pierwszy zastosowali u pszczól alternatywna metodę dostarczania etanolu przez wystawianie ich na opary tej substancji. Pomysł ten inspirowany był badaniami nad muszkami owocowymi, dla których opracowano nawet specjalne urzadzenie (ang. inebriometer) temu służące (MOORE i współaut. 1998). Stosując tę metodę, w ciagu kilku minut można u pszczół zaobserwować brak koordynacji ruchowej i następujące potem zwracanie pokarmu, przewracanie się, a $\mathrm{w}$ końcu całkowite uśpienie, poprzedzone bardzo często niekontrolowanym wyciągnięciem języczka. Uśpienie ustępuje, jeśli ekspozycja na opary kończy się mniej więcej w momencie wyciagania języczka, a prowadzi do całkowitego paraliżu i śmierci, jeśli ekspozycja jest kontynuowana. Metoda ta dostarcza etanol do organizmu pszczół przez układ oddechowy, a nie trawienny, co ma szczególne zastosowania ze względu na ominięcie skutków ubocznych spożycia etanolu powiąanych $\mathrm{z}$ trawieniem i metabolizmem. Może to być wartościowe $\mathrm{w}$ niektórych badaniach, o czym będzie jeszcze mowa. Podobnie jak spożycie $\mathrm{w}$ pokarmie, ekspozycja na opary alkoholu przekłada się na obecność etanolu w hemolimfie pszczół, w której jest obecny do momentu, aż zajdzie pełna detoksykacja. Oznacza to, że powrót do normalnego zachowania następuje prawdopodobnie dopiero wiele godzin po ustapieniu uśpienia oparami etanolu.

W kontekście przywracania organizmu do równowagi po ekspozycji na etanol, ważne wyniki przedstawili HRANITZ i współaut. (2010). Badacze testowali, czy spożycie etanolu przez pszczoły wywołuje u nich stres wyrażony wzrostem stężenia białek szoku cieplnego w tkance mózgowej. Białka te sa uznanym markerem zniszczeń powodowanych właśnie przez stres (GIBNEY i współaut. 2001). Wykazali oni, że kilka godzin po spożyciu niewielkich objętości roztworu $2,5 \%$ i $5 \%$ etanolu rozpuszczonego w roztworze cukru, w mózgach pszczół znaleźć można istotnie wyższe stężenia tych białek niż w mózgach osobników, które spożywaky czysty roztwór cukru. Wskazuje to na intensywna reakcje stresowa po spożyciu etanolu. Te wyniki uświadamiają, że biorąc pod uwagę konsekwencje spożycia - jest mało prawdopodobne, aby pszczoły preferowały bardzo stężone roztwory etanolu, zwłaszcza w warunkach naturalnych lub zbliżonych do naturalnych. 


\section{AGRESJA PO SPOŻYCIU ETANOLU}

Jak wykazał znów ABRAMSON i współaut. (2000), wypicie niewielkiej objętości 1\%, 5\%, 10\% lub 20\% etanolu rozpuszczonego w roztworze cukru nie wpływa na agresję pszczół ujawniającą się w postaci nieprowokowanego wysuwania żądła. Po 5 minutach od spożycia nie wykazali oni żadnych różnic w próbach żądlenia między grupami pszczół, które spożywały wymienione roztwory, a takimi, które piły czysty roztwór cukru. Można jednak argumentować, jak zwrócono uwage powyżej, że 5 minut to czas niewystarczajacy, by pszczoły odczuły skutki spożycia etanolu. Ponadto, można oczekiwać, że nieprowokowana agresja będzie ogólnie rzadka. Rzeczywiście, w późniejszych badaniach terenowych, w których jako miarę agresji wykorzystano liczbę żądeł pozostawionych w skórzanym pasie przymocowanym przy wlocie do ula, wykazano znaczacy wzrost agresji wolno latajacych pszczół w grupie spożywającej etanol w porównaniu do pszczół pijacych czysty roztwór cukru, zwłaszcza w czasie kilku godzin od spożycia (ABRAMSON i współaut. 2004b). Niestety, wykorzystane w tych badaniach pojedyncze wysokie stężenie roztworu etanolu (20\%) sprawiło, że pytanie o wpływ niższych stężeń pozostało bez odpowiedzi. W 2012 r. opublikowano jednak artykuł (WRIGHT i współaut. 2012), w którym opisano eksperyment przeprowadzony w warunkach laboratoryjnych. Obserwowano w nim zachowanie pszczół nakarmionych czystym roztworem cukru (kontrolne) lub roztworem cukru $z$ dodatkiem 5\% lub $10 \%$ etanolu (eksperymentalne) podczas konfrontacji $z$ druga pszczoła (która przed testem otrzymała pokarm bez dodat$\mathrm{ku}$ etanolu). Testy przeprowadzano ponad 2 godziny po karmieniu. Okazało się, że pszczoły nakarmione wcześniej roztworem etanolu, zwłaszcza w stężeniu 10\%, były bardziej agresywne niż pszczoły kontrolne. Agresywność ta wyrażała się przyjmowaniem postawy grożącej. Inni badacze (GIANNONI-GUZMÁN i współaut. 2014) powrócili do badania nieprowokowanego wysuwania żądła i przy zastosowaniu 10-minutowego okresu pomiędzy karmieniem pszczół a testem, odkryli znaczaco zwiększona agresję u pszczół, które spożyły roztwory $10 \%$ i $20 \%$ etanolu rozpuszczonego w roztworze cukru, w porównaniu $z$ osobnikami karmionymi czystym roztworem cukru.

Podsumowujac, większość przeprowadzonych dotąd badań pokazała, iż po spożyciu alkoholu u pszczół obserwuje się zwiększona agresję. Warto jednak zwrócić uwage, iż we wszystkich badaniach po- twierdzających ten efekt u pszczół wykorzystywano stosunkowo wysokie stężenia alkoholu, pomijajacc niskie (około 1\% i niższe).

\section{INNE ZACHOWANIA SPOŁECZNE PO SPOŻYCIU ETANOLU}

Pszczele robotnice często wchodza ze soba w interakcje. Jedna $z$ najbardziej spektakularnych jest taniec. Osobniki zbierajace pokarm w terenie po powrocie do gniazda posługuja się tańcem, aby przekazać innym pszczołom informacje o lokalizacji pokarmu (VON FrIsch 1967). Okazało się, że pszczoły powracajace $z$ karmnika, w którym znalazły roztwór cukru $z$ dodatkiem 5\% lub 10\% etanolu, rzadziej wykonują w ulu tańce niż pszczoły, które znalazły czysty roztwór cukru lub roztwór $z$ dodatkiem $1 \%$ etanolu (BozIC i współaut. 2006). Wskazuje to na brak atrakcyjności pokarmu $z$ duża zawartościa etanolu, do którego pszczoły nie rekrutują innych osobników. Wyniki te warto rozważyć w zestawieniu $z$ tymi przytoczonymi wcześniej, a dotyczacymi preferencji pszczół ujawniających się w odpowiedzi na pokarm zawierajacy etanol. Potwierdzają one bowiem, że pszczoły preferuja raczej niskoprocentowe roztwory etanolu.

Innym typem interakcji robotnic jest trofalaksja, czyli wymiana pomiędzy osobnikami pokarmu lub innych zwiazków chemicznych podczas wzajemnego kontaktu narządów gębowych. Dzięki trofalaksji pszczoły powracajace do ula $z$ nektarem, przekazując go innym robotnicom, informuja je o rodzaju i jakości pożytku występującego poza gniazdem (KORST i VELTHUIS 1982). Jak wykazano, częstość tej interakcji wewnątrz ula maleje po spożyciu przez pszczoły zarówno 5\%, jak i $10 \%$ roztworu etanolu rozpuszczonego w roztworze cukru (BozIC i współaut. 2006). Wyniki dotyczace trofalaksji potwierdzono w późniejszych badaniach (MIXSON i współaut. 2010), ponownie obserwując robotnice wewnatrz ula po spożyciu czystego roztworu cukru lub roztworu $z$ dodatkiem $2,5 \%$ etanolu. Wykazano, że wymiana pokarmu, gdy już do niej dochodzi, trwa krócej, gdy oddaje pokarm pszczoła, która spożyła wcześniej roztwór $z$ dodatkiem etanolu. Warto jednak nadmienić, że innym badaczom nie udało się znaleźć wpływu etanolu na częstotliwość trofalaksji w warunkach laboratoryjnych (WRIGHT i współaut. 2012). Gdy obserwowano pary pszczół, w których jedna robotnica była napojona czystym roztworem cukru lub roztworem 5\% bądź 10\% etanolu rozpuszczonym w roztworze cukru na 2 godziny przed testem, natomiast druga była głodna, to nie znaleziono jasnych różnic w 
częstotliwości wymiany pokarmu między tymi trzema typami par. Wydaje sie jednak, że zachowania społeczne pszczół po spożyciu wysokoprocentowych roztworów etanolu zmieniaja się. Najbardziej prawdopodobnym wyjaśnieniem tego zjawiska jest ogólne działanie etanolu jako inhibitora zachowania.

\section{LOKOMOCJA PO SPOŻYCIU ETANOLU}

ABRAMSON i współaut. (2000) badali, czy spożycie etanolu powoduje u pszczół problemy lokomotoryczne. Wykazali, że już po 5 minutach od spożycia niewielkiej objętości $10 \%$ i $20 \%$ etanolu rozpuszczonego $\mathrm{w}$ roztworze cukru pszczoły staja się powolniejsze $\mathrm{w}$ porównaniu $\mathrm{z}$ osobnikami, które piły czysty roztwór cukru. Pomiary były wykonane na dwa różne sposoby, $z$ wykorzystaniem specjalistycznej aparatury laboratoryjnej inspirowanej wcześniejszymi badaniami nad karaluchami (BALL 1972). MAZE i współaut. (2006), wykorzystując prostszą procedurę wykazali, że pszczoły zamknięte w szalkach po spożyciu $5 \%, 10 \%, 25 \%, 50 \%$ lub $75 \%$ etanolu rozpuszczonego $\mathrm{w}$ roztworze cukru spędzały mniej czasu na chodzeniu, tak jakby sprawiało im ono trudność, w porównaniu do pszczół kontrolnych, które wypiły czysty roztwór cukru. Zjawisko to zależało silnie od dawki: im większe było stężenie wypitego roztworu etanolu, tym wpływ na zachowanie był szybszy i większy. Bardzo podobne wyniki $z$ wykorzystaniem czystego roztworu cukru i 5\% oraz $10 \%$ etanolu rozpuszczonego w roztworze cukru uzyskali WRIGHT i współaut. (2012). Badania potwierdziły więc, że zwłaszcza wysokie stężenia etanolu powoduja u pszczól problemy lokomotoryczne. Potwierdzono ten wniosek obserwacjami prowadzonymi wewnątrz ula (MIXSON i współaut. 2010). Okazało się bowiem, że w naturalnych warunkach pszczoły, które spożyły nieco $2,5 \%$ etanolu rozpuszczonego w roztworze cukru, spędzały mniej czasu na chodzeniu $\mathrm{W}$ porównaniu $\mathrm{z}$ takimi osobnikami, które spożyły nieco czystego roztworu cukru. W przypadku lokomocji wydaje się więc, że nie ma watpliwości co do negatywnego wpływu etanolu, prawdopodobnie także wtedy, gdy spożywany jest on w roztworach o stosunkowo niskim stężeniu. Warto również zwrócić uwagę, że przy ekspozycji pszczół na opary etanolu, skutki lokomotoryczne pojawiaja się w pierwszej kolejności, na długo przed uśpieniem (AMmons i Hunt 2008a).

\section{UCZENIE SIE I PODEJMOWANIE} DECYZJI PO SPOŻYCIU ETANOLU
ABRAMSON i wspólaut. (2000) badali też, jak spożycie etanolu wpływa na uczenie się pszczół. Wykorzystali oni standardowa procedurę, w której bodziec nazywany warunkowym parowany jest $z$ tak zwanym bodźcem bezwarunkowym, który zawsze wywołuje przewidywalna reakcję. Parowanie tych bodźców z czasem powoduje, że reakcja zaczyna pojawiać się w odpowiedzi na bodziec warunkowy (BITTERMAN i współaut. 1983). W przytaczanym eksperymencie bodźcem warunkowym był zapach, bodźcem bezwarunkowym roztwór cukru, a reakcja wyciągnięcie języczka. Procedura wyglądała w taki sposób, że pszczołę eksponowano na zapach, a zaraz potem stymulowano jej czułki roztworem cukru, który po wyciagnięciu języczka dostawała do spróbowania. Pszczoły typowo po kilku próbach (2-4) zaczynaja wyciagać języczki, gdy tylko poczuja zapach powiazany poprzednio $z$ podawaniem cukru (ale nie inny). W tych badaniach autorzy wykazali, że spośród pszczół spożywających niewielkie objętości czystego roztworu cukru albo $1 \%, 5 \%$, $10 \%$ lub $20 \%$ etanolu rozpuszczonego w roztworze cukru, po 5 minutach od spożycia jedynie pszczoły, które piły roztwór o stężeniu $20 \%$ miały ewidentnie zaburzony proces uczenia się. U tych pszczól, nawet 12 przypadków sparowania bodźców nie skutkowało pojawieniem się reakcji $\mathrm{w}$ odpowiedzi na zapach. Słabiej zaznaczony skutek niższych dawek etanolu można tu przypisać krótkiemu okresowi pomiędzy spożyciem etanolu a testem. Rzeczywiście, w późniejszych badaniach (MUSTARD i współaut. 2008) wykazano, że spośród pszczół spożywających niewielkie objętości czystego roztworu cukru albo takiego $z$ dodatkiem $5 \%, 10 \%$ lub $25 \%$ etanolu, po 2 godzinach od spożycia pszczoły, które piły roztwór o stężeniu 5\% lub bardziej stężony, miały wyraźnie zaburzone uczenie się. Wyrażało się to wolniejszym tempem uczenia się związku między bodźcem warunkowym a bezwarunkowym. Skutek ten był najbardziej widoczny u pszczół, które spożywały $25 \%$ roztwór etanolu, gdyż zdecydowana większość $z$ nich w ogóle nie nauczyła się reakcji na zapach, mimo 8 przypadków sparowania bodźców. Dalsze badania, w których zastosowano 10-minutowy okres między spożyciem różnych typów roztworów a początkiem testowania, przyniosły podobne wnioski, choć wyniki były mniej jednoznaczne niż przy okresie dwugodzinnym (ABRAMSON i współaut. 2015). Wydaje się więc, że już stosunkowo niskie stężenia wypitego roztworu etanolu znacząco pogarszaja uczenie się pszczół. Co istotne, jak przekonujacco argumentuja MUSTARD i współaut. (2008), skutki, jakie spożycie etanolu wywiera na uczenie się pszczół nie sa 
pochodna np. trudności lokomotorycznych, które też wydaja się ujawniać przy stosunkowo niskich stężeniach spożytego alkoholu. Reakcja obserwowana i wskazujaca na uczenie się, czyli wyciaganie języczka, jest dość prosta. Gdyby to trudności lokomotoryczne w wyciaganiu języczka miały wyjaśniać, dlaczego po spożyciu etanolu robotnice wolniej ucza się związku między bodźcem bezwarunkowym a warunkowym, to należałoby oczekiwać różnic, np. w szybkości wyciagania języczka przez pszczoły, które spożywały czysty roztwór cukru i taki $z$ dodatkiem etanolu. Tymczasem badacze nie wykazali takich różnic w odpowiedzi na ewidentnie atrakcyjny roztwór cukru i stężeń 2,5\%,5\% i 10\% etanolu (MUSTARD i współaut. 2008).

Często wykorzystywanym sposobem badania podejmowania decyzji u pszczół jest obserwacja wyboru kwiatów dostępnych na sztucznej łace do furażowania, czyli zbierania pokarmu (ABRAMSON i współaut. 2005). Łaka taka w najprostszej formie składa się $z$ plastikowego, zamykanego szczelnie pudła $Z$ kwiatami w formie różnokolorowych pojemników wypełnionych pokarmem (roztworem cukru). Pszczoła wpuszczona na łakę zapoznaje się $z$ kwiatami i musi dokonać wyboru tego, na którym się pożywi. Jeśli jakość pokarmu na łace systematycznie różni się pomiędzy kolorami kwiatów, np. gdy kwiaty niebieskie zawieraja $20 \%$, a białe $40 \%$ roztwór cukru, to pszczoły zorientuja się w tym i będa wybierać te bardziej opłacalne $z$ energetycznego punktu widzenia, czyli kwiaty białe. Podobnie dzieje się, gdy kwiaty różnią się nie jakością pokarmu, a jego ilościa, np. gdy kwiaty niebieskie zawieraja $5 \mu 1$, a białe $10 \mu$ tego samego rodzaju pokarmu pszczoły będą częściej wybierać kwiaty białe. To typowe zjawisko zanika jednak, gdy w pokarmie znajduje się etanol w stężeniu $2,5 \%$ (ABRAMSON i współaut. 2005). Wtedy pszczoły losowo pożywiaja się na kwiatach niebieskich lub białych, mimo że różnią się one jakością lub ilościa pokarmu. Potencjalnym powodem takiej zmiany jest to, że etanol obecny w pokarmie w jakiś sposób utrudnia pszczołom percepcję jakości lub ilości pokarmu, bądź zakłóca zapamiętywanie różnic między kwiatami. Jest to $z$ pewnościa kwestia oczekująca na dalsze badania, a jest szczególnie interesująca w kontekście ekologicznym i naturalnych warunkach terenowych.

\section{ANALGEZJA PO SPOŻYCIU ALKOHOLU}

Badania GIANNONI-GUZMÁN i współaut. (2014) koncentrowały się na odczuwaniu bólu przez pszczoły oraz na tym, czy etanol działa na nie analgetycznie, zmniejszając od- czuwanie bólu. Oczywiście, jak u wszystkich zwierzat, badanie bólu nie może być przeprowadzone na zasadzie wywiadu - zamiast tego należy wybrać odpowiedni wskaźnik w zachowaniu lub fizjologii, o którym sacdzi się, że świadczy o odczuwaniu bólu. Autorzy jako taki wskaźnik wybrali wysunięcie żądła w odpowiedzi na szok elektryczny. Grupy pszczół karmili czystym roztworem cukru albo $z$ dodatkiem 2,5\%, 5\%, 10\% lub 20\% etanolu, a po 10 minutach od karmienia przeprowadzali testowanie. Razili pszczoły prądem o napięciu rosnaccym o $1 \mathrm{~V}$ (od 1 do $30 \mathrm{~V}$ ) tak długo, aż pszczoła zareagowała wysunięciem żądła. Reakcję taka interpretowali jako odpowiedź bólową na stymulację pracem. Wykazali oni, że pszczoły, które spożyły czysty roztwór cukru odczuwaja ból przy drażnieniu prądem o napięciu około 7 V. Etanol natomiast zmniejszał istotnie odczuwanie bólu już w stężeniu 2,5\%, przy czym efekt ten był najbardziej widoczny po spożyciu $20 \%$ etanolu rozpuszczonego w roztworze cukru.

\section{TOKSYCZNOŚĆ ETANOLU I ŚMIERTELNOŚ PO JEGO SPOŻYCIU}

W badaniach MAZE i współaut. (2006) wykazano, że dopiero spożycie 50\% etanolu rozpuszczonego $\mathrm{w}$ roztworze cukru skutkowało zwiększona śmiertelnością pszczół w okresie 48 godzin po spożyciu. Niższe stężenia etanolu (5\%, $10 \%$ i $25 \%)$ nie skutkowały śmiertelnościa większa niż w kontrolnej grupie pszczół, która wypijała czysty roztwór cukru. W tych badaniach, ekspozycja na dany typ roztworu nasteppowała tylko raz i była to niewielka objętość, tak więc wnioski, które można $z$ nich wyciagnać sa dość ograniczone. W późniejszych badaniach (MUSTARD i współaut. 2019), pszczoły przetrzymywano w klatkach $z$ dostepem do czystego roztworu cukru badź takiego $z$ dodatkiem $1,25 \%, 2,5 \%$ lub $5 \%$ etanolu przez okres kilkunastu dni. Stwierdzono wtedy, że w porównaniu do pszczół przetrzymywanych w klatkach $z$ dostepem do czystego roztworu cukru, osobniki spożywające roztwory 2,5\% i 5\% etanolu wykazywały zwiększona śmiertelność. Skutku takiego nie wykryto w przypadku $1,25 \%$ roztworu etanolu, co wskazuje na to, że pszczoły dobrze radza sobie $z$ ciągłym kontaktem $z$ niskoprocentowymi roztworami etanolu.

\section{ZMIENNOŚĆ SKUTKÓW DZIAŁANIA ETANOLU}

Najbardziej oczywistym źródłem zmienności skutków działania etanolu jest jego dawka. Jednak nawet, gdy bierze się pod 
uwage jakąkolwiek pojedyncza dawkę etanolu, to robotnice $z$ różnych rodzin pszczelich rozciagaja się na kontinuum od takich, które maja niska wrażliwość, do takich, które mają wysoką wrażliwość na jej działanie (AMmONs i HunT 2008a). Stąd kluczowe jest zawsze wykorzystywanie w badaniach jak największej liczby niespokrewnionych rodzin pszczelich, aby przybliżyć się do jak najlepszego uwzględniania tej zmienności. Zidentyfikowano szereg genów odpowiedzialnych za różnice we wrażliwości na etanol u pszczół, powiazanych $z$ takimi aspektami funkcjonowania jak transmisja synaptyczna, wzrost i różnicowanie neuronów, synteza i metabolizm tłuszczów, detoksykacja, absorpcja i metabolizm etanolu i innymi (AMMONs i HunT 2008b). Nawet w obrębie pojedynczej rodziny pszczelej osobniki ewidentnie bardzo różnią się wrażliwościa na etanol, a tym samym siła skutku, jaki on wywołuje, np. w zakresie wzbudzanej preferencji (SoKOLOWSKI i współaut. 2012). Aktualnie niewiele wiadomo na temat konkretnych powodów takich różnic, a przewidywanie skutków działania etanolu na różne robotnice jest trudne.

W najnowszych badaniach (Miler i współaut. 2021), w których wystawiano pszczoły na opary etanolu i mierzono czas potrzebny do ich całkowitego uśpienia wykazano, że jednym ze źródeł różnic we wrażliwości na etanol jest przynależność kastowa robotnic. Ta przynależność u pszczół oparta jest przede wszystkim na wieku, a ściślej mówiąc na oczekiwanej długości życia. Osobniki młodsze (o wyższej oczekiwanej długości życia) pozostaja zawsze w ulu i pracuja wewnattrz gniazda przy zadaniach takich jak opieka nad potomstwem. Osobniki starsze (o niższej oczekiwanej długości życia) opuszczają ul w ciagu dnia i pracują w terenie przy zadaniach bardziej ryzykownych, takich jak furażowanie. Jeśli chodzi o działanie etanolu, to wbrew temu, że ogólna odporność na stres i czynniki toksyczne spada u pszczół $z$ wiekiem, to osobniki starsze radza sobie $z$ wpływem etanolu lepiej niż osobniki młodsze. Jako miarę odporności na etanol wykorzystano czas w jakim pszczoła uległa zupełnej sedacji (uśpieniu) po kontakcie $z$ oparami 98\% alkoholu etylowego. Dodatkowo, w tkankach osobników starszych stwierdzono znaczaca aktywność dehydrogenazy alkoholowej, enzymu, który nie jest obecny u osobników młodszych, ale może grać istotna rolę w rozkładzie spożytego etanolu. Wobec tego wydaje się, że starsze osobniki moga sporadycznie spotykać się $z$ alkoholem w środowisku naturalnym, co tłumaczyłoby ich przystosowania do zetknięcia się $z$ ta substancją. Miejscem, w którym najprawdopodobniej się $z$ nim spotykaja sa kwiaty, a dokładniej nektar kwiatowy, a może także fermentujace opadłe owoce. Obecne w nektarze drożdże maja zdolność rozkładu cukru do alkoholu w procesie fermentacji i w sprzyjajacych warunkach pogodowych takie zjawisko może mieć miejsce (JAKUBSKA i współaut. 2005, GOODRICH i współaut. 2006). Aktualnie natomiast niewiele jest danych terenowych rzeczywiście to pokazujących. Stężenia etanolu w nektarze kwiatowym, gdy już się pojawiają, $z$ pewnością sa niskie, a więc stanowia roztwory, o których wpływie na pszczoły wiadomo najmniej. Przytoczone badania demonstruja użyteczność metodologii polegajacej na wystawianiu pszczół na opary alkoholu, gdy porównywane są różnowiekowe osobniki.

\section{WIELOKROTNA EKSPOZYCJA NA ETANOL}

Spośród dotychczas przytoczonych badań, jedynie kilka skupiało się jakkolwiek na wielokrotnej ekspozycji pszczół na etanol. $\mathrm{Na}$ przykład SoKolowsKI i współaut. (2012) badali charakterystyki wizyt przy karmniku $z$ 5\% roztworem etanolu rozpuszczonym w roztworze cukru w ciagu pojedynczego dnia, kiedy te same pszczoły odwiedzały karmnik wiele razy, a więc spożywały roztwór etanolu wielokrotnie. Innym przykładem sa badania MUSTARD i współaut. (2019), w których pszczoły przetrzymywano w klatkach przez kilkanaście dni $z$ dostępem do roztworu cukru bez etanolu lub $z$ dodatkiem $1,25 \%, 2,5 \%$ lub $5 \%$ etanolu, a notowano ich śmiertelność. Choć badanie wpływu pojedynczej ekspozycji może być pouczajace i ważne, to jednak powtarzajacy się kontakt $z$ etanolem i jego wpływ na zachowanie pszczół jest szczególnie interesujacy, ponieważ mówi więcej o przydatności tych owadów w badaniach nad alkoholizmem. Wydaje się, że możliwości stosowania pszczół w tych badaniach sa znaczne, głównie za sprawa wspomnianych wcześniej wyników wskazujacych na brak awersji smakowej u pszczół spożywajacych etanol (VARNON i współaut. 2018). Brak tej awersji jest charakterystyczny dla alkoholików oraz wykorzystywanych w badaniach zwierzecych modeli alkoholizmu, u których warunkiem koniecznym jest, by zwierzę spożywało etanol dobrowolnie i wielokrotnie.

Miler i współaut. (2018) badali występowanie u pszczół innej charakterystycznej cechy alkoholizmu, a mianowicie tolerancji na działanie etanolu. Tolerancja jest zjawiskiem często towarzyszacym używaniu leków czy substancji psychoaktywnych. Polega na tym, że wraz $z$ powtarzajaca się ekspozycja na dana substancję, wywołanie tego samego 
skutku w zachowaniu wymaga wzrastajacej dawki dostarczanej do organizmu albo czasu ekspozycji na tę samą dawkę (FADDA i RosSETTI 1998). MiLER i współaut. (2018) badali to zjawisko wykorzystując ekspozycje pszczół na opary etanolu przez 5 kolejnych dni, za każdym razem wystawiajac robotnice na jego działanie przez 3 minuty. Odkryli, że po 5 dniach powtarzającej się ekspozycji wpływ etanolu na lokomocję pszczół (ogólne spowolnienie) był dwukrotnie mniejszy niż na początku. Nie był to efekt tego, że robotnice się zestarzały, gdyż osobniki w tym samym wieku, ale wystawione na opary etanolu po raz pierwszy, wykazywały znaczaco większe spowolnienie. W kontekście wpływu etanolu, wystepowanie tolerancji i brak awersji smakowej wskazuja na to, że pszczoły moga być prawdopodobnie $z$ sukcesem wykorzystywane jako model w badaniach nad alkoholizmem. Innymi słowy, wydaje się prawdopodobne, że w warunkach laboratoryjnych uda się stworzyć pszczołom warunki, w których rozwina uzależnienie od alkoholu. Biorac pod uwage unikatowe cechy pszczoły miodnej, otworzy to wiele nowych perspektyw badawczych.

\section{KONKLUZJE I PERSPEKTYWY}

Przeprowadzone do tej pory badania jasno wskazują, iż pszczoły stają się obiecujacym modelem w badaniach zwiazanych ze spożywaniem i nadużywaniem alkoholu. Dotychczasowe doświadczenia skupiaja się na wpływie pojedynczej ekspozycji o wysokim stężeniu etanolu na robotnice. Tak odurzane alkoholem robotnice wykazuja trudności w lokomocji, zwracaja spożyty pokarm, a także zapadaja w stan uśpienia. Mają także trudności w podejmowaniu decyzji, uczeniu się czy komunikacji z innymi osobnikami. Moga również wykazywać zwiększona agresję. Te skutki spożycia alkoholu są uderzajaco podobne do obserwowanych u człowieka czy innych ssaków. Badania, choć dostarczaja istotnych wskazówek dotyczacych dalszych kroków badawczych, nie moga być jednak uznane za w pełni satysfakcjonujace. Rozmijają się bowiem $z$ wykazanymi u pszczół preferencjami niskoprocentowych roztworów etanolu, a także w większości pomijaja procesy zwiazane $z$ wielokrotna ekspozycją na alkohol. W tym kontekście, bardzo niewiele wiadomo o tym, jak etanol wpływa na pszczoły. Bardzo prawdopodobnym jest, iż robotnice stosunkowo często maja kontakt $z$ etanolem w warunkach naturalnych. Świadczą o tym choćby różne przystosowania do radzenia sobie $z$ działaniem tej substancji. Niewiadoma pozostaje jednak, jak często pszczoły majac okazję spożywać pokarm $z$ alkoholem, a także $w$ jakich stężeniach etanol występuje w środowisku naturalnym pszczół. Ważnym i nieodzownym elementem badań nad spożyciem alkoholu przez pszczoły jest zatem przeprowadzenie serii eksperymentów sprawdzajacych, jakie stężenia etanolu faktycznie pszczoły spotykaja w terenie. Przypuszczalnie bowiem, jeśli występuje on w nektarze, to najprawdopodobniej w niewielkich ilościach. Wobec tego, najlepszym sposobem badania zagadnień związanych $z$ alkoholizmem u pszczół wydaje się ciagłe (wielokrotne) wystawianie ich na niewielkie lub powoli rosnace stężenia etanolu. Brak awersyjności w stosunku do smaku i wytworzenie tolerancji na jego działanie stanowią aktualnie główne przesłanki świadczące o tym, że takie uzależnienie jest u nich możliwe.

Alkohol jest substancją, której spożycie niesie za soba zarówno pozytywne, jak i negatywne konsekwencje. $Z$ jednej strony długotrwałe spożywanie alkoholu może prowadzić do rozwoju uzależnień, a jego nadużywanie zaburza wiele form zachowania, w tym także społecznych, np. zwiąanych z komunikacją. Wartym zbadania jest nie tylko występowanie u pszczół potencjalnego wpływu nadużywania alkoholu na danego osobnika, ale również odpowiedzi pozostałych członków gniazda na zachowania "pijanych” sióstr. Możliwe bowiem, że pijane pszczoły, jako mniej przydatne lub szkodliwe w gnieździe, w ogóle nie sa do niego wpuszczane. $Z$ drugiej strony natomiast, alkohol jest substancją znaną również ze swojego korzystnego wpływu na niektóre aspekty funkcjonowania organizmu. Jeśli pszczoły stykaja się $z$ alkoholem w swoim środowisku naturalnym, przypuszczalnie moga korzystać $z$ jego dobroczynnego działania, np. stosować go jako medykament $w$ walce $z$ chorobami. Dzięki dotychczas uzyskanym wynikom badań pszczoła miodna staje się przekonujacym gatunkiem modelowym w badaniach zwiazanych ze spożywaniem, nadużywaniem i uzależnieniem od alkoholu. Wiele kwestii pozostaje nadal nieodkrytych, co otwiera szeroka perspektywę dalszych badań z wykorzystaniem pszczół.

\section{PODZIĘKOWANIE}

Dziękujemy dr Joannie Kajzer-Bonk za krytyczne uwagi do manuskryptu.

\section{Streszczenie}

Mimo rosnacej wiedzy i coraz nowocześniejszych metod leczenia, alkoholizm nadal stanowi poważny, globalny problem, wymagający dalszych badań o szerokim zakresie. Biorąc pod uwagę, iż badania $z$ udziałem ludzi posiadaja ograniczenia i rodza wiele dylematów etycznych, szeroko wykorzystuje się modele zwierzęce. Perspektywicznym gatunkiem modelowym w badaniach nad konsumpcja i zaburzeniami zwiąanymi z nadużywaniem 
alkoholu stała się w ostatnim czasie pszczoła miodna Apis mellifera. Szereg przeprowadzonych dotychczas badań pokazał, iż pszczoły nie tylko chętnie spożywają pokarm $z$ dodatkiem niskoprocentowego alkoholu, ale również pod jego wpływem pojawiają się u nich modyfikacje zachowania podobne jak u ludzi. Co więcej, brak awersji smakowej w stosunku do alkoholu, a także wzrost tolerancji przy wielokrotnym kontakcie $z$ alkoholem wskazuja, iż pszczoły moga wykazywać predyspozycje do uzależnienia od alkoholu. Przeprowadzone do tej pory badania nie tylko potwierdzaja odpowiedniość pszczoły miodnej jako gatunku modelowego w kontekście spożywania alkoholu, ale także otwierają szeroka perspektywę dalszych badań nad wpływem alkoholu na fizjologię i behawior pszczoły miodnej.

\section{LITERATURA}

Abramson C. I., STONE S. M., ORTEZ R. A., LUCCARDI A., VANN K. L., HANIG K. D., RICE J., 2000. The development of an ethanol model using social insects I: Behavior studies of honeybee (Apis mellifera). Alcohol. Clin. Exp. Res. 24, 1153-1166.

ABramson C. I., Fellows G. W., Browne B. L., LAWSON A., ORTIZ R. A., 2003. Development of ethanol model using social insects II: Effect of Antabuse on consummatory responses and learned behavior of the honey bee (Apis mellifera L.). Psych. Rep. 92, 365-378.

ABRAMSON C. I., KANDOLR A., SHERIDAN A., DONOHUE D., BOZIC J., MEYers J., BenBassat D., 2004a. Development of ethanol model using social insects III: Preferences for ethanol solutions. Psych. Rep. 94, 227-239.

Abramson C. I., Place A. J., Aouino I. S., FerNANDES A., 2004b. The development of an ethanol model using social insects IV: Influence of ethanol on the aggression of Africanized honey bees. Psych. Rep. 94, 1107-1115.

ABRAMSON C. I., SANDERSON C., PAINTER J., BARNETT S., WELLS H., 2005. The development of an ethanol model using social insects V: Honey bee foraging decisions under the influence of alcohol. Alcohol 36, 187-193.

ABRAMSON C. I., CRAIG D. P. A., VARnon C. A., WELLS H., 2015. The effect of ethanol on reversal learning in honey bees (Apis mellifera anatolica): Response inhibition in a social insect model. Alcohol 49, 245-258.

Ammons A. D., HunT G. J., 2008a. Characterization of honey bee sensitivity to ethanol vapor and its correlation with aggression. Alcohol 42, 129-136.

Ammons A. D., Hunt G. J., 2008b. Identification of quantitative trait loci and candidate genes influencing ethanol sensitivity in honey bees. Behav. Genet. 38, 531-553.

BALL H. J., 1972. A system for recording activity of small insects. J. Econ. Entomol. 65, 129132 .

BitTERMAn M. E., MENZEL R., FIETZ A., SCHÄFER S., 1983. Classical conditioning of proboscis extension in honeybees (Apis mellifera). J. Comp. Psychol. 97, https://doi. org/10.1037/0735-7036.97.2.107.

BOzIC J., ABRAMSON C. I., BEDENCIC M., 2006. Reduced ability of ethanol drinkers for social communication in honeybees (Apis mellifera carnica Poll.). Alcohol 38, 179-183.

BOZIC J., DicEsare J., WELls H., ABRAMSON C. I. 2007. Ethanol levels in honeybee hemolymph resulting from alcohol ingestion. Alcohol 41, 281-284.
FADDA F., RossetTI Z. L., 1998. Chronic ethanol consumption: from neuroadaptation to neurodegeneration. Prog. Neurobiol. 56, 385-431.

GARCIA J., KoElliNG R. A., 1966. Relation of cue to consequence in avoidance learning. Psychon. Sci. 4, 23-124.

Giannoni-GuZmán M. A., Giray T., Agosto-Rivera J. L., Stevison B. K., Freeman B., RicCi P., BRown E. A., ABRAMSON C. I., 2014. Ethanolinduced effects on sting extension response and punishment learning in the western honey bee (Apis mellifera). PLoS One 9, http:// doi.org/10.1371/journal.pone.0100894.

GHOSH DASTIDAR S., WARNER J. B., WARNER D. R., MCCLAIN C. J., KIRPICH I. A., 2018. Rodent models of alcoholic liver disease: role of binge ethanol administration. Biomolecules 8, https://doi.org/10.3390/biom8010003

GiBney E., GaulT J., Williams J., 2001. The use of stress proteins as a biomarker of sub-lethal toxicity: induction of heat shock protein 70 by 2-isobutyl piperidine and transition metals at sub-lethal concentrations. Biomarkers 6, 204 217 .

GOODRICH K. R., ZJHRA M. L., LEY C. A., RAGUSO R. A., 2006. When flowers smell fermented: the chemistry and ontogeny of yeasty floral scent in pawpaw (Asimina triloba, Annonaceae). Int. J. Plant Sci. 167, 33-46.

HRANITZ J. M., ABRAMSON C. I., CARTER R. P., 2010. Ethanol increases HSP7O concentration in honeybee (Apis mellifera L.) brain tissue. Alcohol 44, 275-282.

JAKUBSKA A., PRZADO D., STEININGER M., ANIOL-KWIATKOWSKA J., KADEJ M., 2005. Why do polinators become sluggish? Nectar chemical constituents from Epipactis helleborine (L.) Crantz (Orchidaceae). Appl. Ecol. Environ. Res. 3, 29-38.

Klosterhalfen S., Klosterhalfen W., 1985. Conditioned taste aversion and traditional learning. Psychol. Res. 47, 71-94.

Korst P. J. A. M., Velthuis H. H. W., 1982. The nature of trophallaxis in honeybees. Insectes Soc. 29, 209-221.

MAZE I. S., WRight G. A., Mustard J. A., 2006. Acute ethanol ingestion produces dose-dependent effects on motor behavior in the honeybee (Apis mellifera). J. Insect Physiol. 52, 12431253.

McGovern P. E., ZHANG J., TANG J., ZhANG Z., Hallg. R., Moreau R. A., NuñeZ A., Butrym E. D., RichardS M. P. WANG C., CHENG G., ZHAO Z., WANG C., 2004. Fermented beverages of pre- and proto-historic China. Proc. Natl. Acad. Sci. USA 101, 17593-17598.

MENZEL R., 2012. The honeybee as a model for understanding the basis of cognition. Nat. Rev. Neurosci. 13, 758-768.

Miler K., Kuszewska K., Privalova V., WoycieCHOWSKI M., 2018. Honeybees show adaptive reactions to ethanol exposure. Sci. Rep. 8, 1-6. http://doi.org/10.1038/s41598-01827117

Miler K., Stec D., Kamińska A., Pardyak L., KuSZEWSKA K., 2021. Alcohol intoxication resistance and alcohol dehydrogenase levels differ between the honeybee castes. Apidologie 52, 230-241.

MiXson T. A., ABRAmson C. I., BOZIC J., 2010. The behavior and social communication of honey bees (Apis mellifera carnica Poll.) under the influence of alcohol. Psych. Rep. 106, 701-717.

Moore M. S., Dezazzo J., LuK A. Y, Tully T., Singh C. M., Heberlein U., 1998. Ethanol in- 
toxication in Drosophila: Genetic and pharmacological evidence for regulation by the cAMP signaling pathway. Cell 93, 997-1007.

MustaRD J. A, EDGAR E. A., MAZADE R. E., Wu C., Lillvis J. L., WRIGHT G. A., 2008. Acute ethanol ingestion impairs appetitive olfactory learning and odor discrimination in the honeybee. Neurobiol. Learn. Mem. 90, 633-643.

Mustard J. A., Oquita R., Garza P., Stoker A., 2019. Honey bees (Apis mellifera) show a preference for the consumption of ethanol. Alcohol. Clin. Exp. Res. 43, 26-35.

SchOlz H., MustaRD J. A., 2013. Invertebrate Models of Alcoholism. Curr. Top. Behav. Neurosci. 13, 433-457.

Sokolowski M. B. C., Abramson C. I., CRAig D. P. A., 2012. Ethanol self-administration in free-flying honeybee (Apis mellifera L.) in an operant conditioning protocol. Alcohol. Clin. Exp. Res. 36, 1568-1577.

SPANAGEL R., 2000. Recent animal models of alcoholism. Alcohol Res. Health 24, 124-131.
VARNon C. A., Dinges C. W., Black T. E., Wells H., ABRAMSON C. I., 2018. Failure to Find Ethanol-Induced Conditioned Taste Aversion in Honey Bees (Apis mellifera L.). Alcohol. Clin. Exp. Res. 42, 1260-1270. http://doi. org/10.1111/acer.13761.

VON FRISCH K., 1967. The Dance Language and Orientation of Bees. Harvard University Press, Cambridge.

WinSTON M. L., 1987. The biology of the honey bee. Harvard University Press, Cambridge, USA.

Wright G. A., Lillvis J. L., Bray H. J., Mustard J. A., 2012. Physiological state influences the social interactions of two honeybee nest mates. PLoS One 7, http://doi.org/10.1371/ journal.pone.0032677.

ZAYED A., RoBINSON G. E., 2012. Understanding the relationship between brain gene expression and social behavior: lessons from the honey bee. Ann. Rev. Gen. 46, 591-615.

KOSMOS Vol. 70, 4, 659-669, 2021

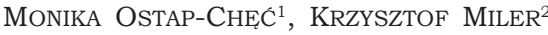

${ }^{1}$ Institute of Environmental Sciences, Faculty of Biology, Jagiellonian University, 7 Gronostajowa Str., $30-387$ Kraków, ${ }^{2}$ Institute of Systematics and Evolution of Animals PAS, 17 Sławkowska Str., 31-016 Kraków, e-mail: monika.ostap-chec@doctoral.uj.edu.pl, miler@isez.pan.krakow.pl

\section{THE HONEYBEE AS A PROMISING MODEL SPECIES IN ALCOHOLISM RESEARCH}

\section{Summary}

Despite growing knowledge and increasingly advanced methods of treatment, alcoholism still poses a serious, global problem that requires further extensive research. Considering that human research has limitations and raises many ethical issues, animal models are widely used in this type of research. The honeybee Apis mellifera has recently emerged as a prospective model species for studies devoted to alcohol consumption and abusive use. Numerous studies conducted to date have shown that honeybees not only willingly consume food spiked with low-level alcohol, but that under its influence they display behavioural changes similar to those observed in humans. Moreover, a lack of taste aversion to alcohol and an increase in tolerance when exposed to alcohol repeatedly, indicate that bees might show predispositions to alcohol dependence. Research conducted to date not only confirms the suitability of the honeybee as a model species in the context of alcohol consumption, but also opens a wide perspective for further studies related to the effects of alcohol on physiology and behaviour of the honeybee. 